\title{
The effect of bale density and addition of formic acid on the in situ dry matter and crude protein degradation of lucerne, red clover and red fescue silages
}

\author{
C. Purwin ${ }^{1,4}$, M. Fijałkowska', B. Kowalik² ${ }^{2}$ H. Skórko-Sajko', Z. Nogalski ${ }^{3}$ and B. Pysera' ${ }^{1}$ \\ 'University of Warmia and Mazury, Department of Animal Nutrition and Feed Science \\ Oczapowskiego 5, 10 -718 Olsztyn, Poland \\ ${ }^{2}$ The Kielanowski Institute of Animal Physiology and Nutrition, Polish Academy of Sciences \\ 05-110 Jabłonna, Poland \\ ${ }^{3}$ University of Warmia and Mazury, Department of Cattle Breeding and Milk Quality Evaluation \\ Oczapowskiego 5, 10-718 Olsztyn, Poland
}

KEY WORDS: lucerne, red clover, red fescue, silages, in situ degradability, bale density, formic acid

Received: 3 March 2013

Revised: 14 February 2014

Accepted: 12 June 2014

${ }^{4}$ Corresponding author:

e-mail: purwin@uwm.edu.pl
ABSTRACT. The effect of bale density (low: 122-127 $\mathrm{kg}$ dry matter (DM) $\cdot \mathrm{m}^{-3}$ vs high: $\left.189-190 \mathrm{~kg} \mathrm{DM} \cdot \mathrm{m}^{-3}\right)$ and the addition of formic acid $\left(5 \mathrm{I} \cdot \mathrm{t}^{-1}\right)$ on the in situ DM and crude protein (CP) degradation of wilted lucerne (Medicago sativa L.), red clover (Trifolium pratense L.) and red fescue (Festuca rubra) silages was determined. The effective DM degradability of lucerne, red clover and red fescue silages reached $59.8 \%, 52.8 \%$ and $51.9 \%$, respectively, that of $\mathrm{CP}, 69.5 \%, 55.8 \%$ and $58.4 \%$, respectively. High bale density decreased $(P<0.05)$ only DM degradability $(53.9 \%$ vs $49.5 \%)$ and the a-value of red clover silage. The addition of formic acid had no effect on the DM degradability of silages. Bale density and formic acid, and their interaction, exerted the most significant effect on the effective degradation of CP and the content of rapidly degradable fraction a of lucerne silage. The effective degradation of DM and $\mathrm{CP}$ of red fescue silage was not affected by the experimental factors.

\section{Introduction}

The quality of feeds for ruminants is largely determined by the nutritional value of protein, including protein that is not degraded in the rumen. Fermentation processes during the ensiling of green forage lead to numerous quantitative and qualitative changes in nutrient fractions, mostly in proteins and carbohydrates. During the ensiling process, plant proteases and peptidases convert most of the plant protein to free amino acids, ammonia nitrogen, and other forms of non-protein nitrogen (NPN). Most protein transformations in silo result from the presence of plant proteases and peptidases. The factors that determine the rate and extent of proteolysis during ensilage include dry matter (DM) content, $\mathrm{pH}$, temperature, and the presence of proteolysis inhibitors typical for a given plant species (Slottner and Bertilsson, 2006). DM content and pH are considered the most important factors, whereas plant species has a profound effect on the rate of proteolysis at lower DM contents (Jones, 2000). 
Guo et al. (2007), who investigated changes in the activity levels of plant proteases during ensilage of lucerne treated with different additives, point to the important role played by proteolytic enzymes such as carboxypeptidase, aminopeptidase and acid proteinase; these enzymes differ with respect to $\mathrm{pH}$ and temperature optima and in their sensitivity to inhibitors.

The research conducted to date has tended to focus on the effect of wilting and additives on the rate of fermentation, aerobic stability and the microbiological quality of baled silages. Little attention has been paid, however, to the effect of bale density on nitrogen fraction composition, crude protein (CP) degradation in the rumen, and soluble protein values.

Purwin (2007) demonstrated that the effects of wilting degree and additive treatments on silage fermentation in bales are ambiguous and uncertain. Thus, the technology of bale silage production should be further improved, including the use of high-efficiency balers to allow for higher compression and better anaerobic conditions in bales. Other authors (Han et al., 2006) investigated the effect of bale density on carbohydrate fermentation and baled silage storage, but they did not analyse the correlation between bale density and proteolysis rate. According to Slottner and Bertilsson (2006), an increase in DM content and the use of chemical and biological additives reduce the rate of proteolysis during ensiling, while proteolysis is not affected by the ensiling method (cylindrical bales vs horizontal silos). The cited authors demonstrated that wholecrop harvesting with roll-balers decreases protein degradability as compared with a chopped crop ensiled in a silo. Due to its effect on aerobic conditions (the amount of oxygen trapped in the forage mass and porosity levels), bale density also influences temperature and fermentation intensity, thus affecting protein solubility and the activity of plant proteases responsible for the hydrolysis of nitrogen compounds during ensilage and the susceptibility of protein to microbial degradation in the rumen.

In view of the above, the objective of this study was to determine the effect of bale density (low vs high) and the addition of formic acid on the in situ DM and CP degradation of wilted lucerne (Medicago sativa $\mathrm{L}$.) and red clover (Trifolium pratense L.) silages. A sample of red fescue (Festuca rubra) was used as a model temperate grass species from seminatural grasslands.

\section{Material and methods}

\section{Silage making}

Silages were made from the first harvests of lucerne cv. Alba, red clover cv. Nike and red fescue cv. Godolin in their second year of growth. The crops were grown in pure stands at the Experimental Station of the University of Warmia and Mazury in Łężany (Poland). The forage was wilted for $48 \mathrm{~h}$, and tedded once. The dry matter content of ensiled materials ranged from $41 \%$ to $43 \%$ (see experimental design). Harvested crops were compressed with two types of roll-balers, SIPMA (low bale density, 120 $\mathrm{kg} \mathrm{DM} \cdot \mathrm{m}^{-3}$ ) and CLAAS (high bale density, $200 \mathrm{~kg}$ $\mathrm{DM} \cdot \mathrm{m}^{-3}$ ). The crops were ensiled without additives and with the addition of $80 \%$ formic acid (FA), a proteolysis inhibitor, which was sprayed onto wilted forage, in the amount of $51 \cdot \mathrm{t}^{-1}$. A total of 36 bales were made, according to the following experimental design:

\begin{tabular}{|c|c|c|c|c|c|c|c|c|c|c|}
\hline \multirow{2}{*}{ Specification } & \multicolumn{3}{|c|}{ Lucerne } & \multicolumn{3}{|c|}{ Red clover } & \multicolumn{4}{|c|}{ Red fescue } \\
\hline & \multicolumn{3}{|c|}{$\overline{\text { LO LA HO HA }}$} & \multicolumn{3}{|c|}{ LO LA HO HA } & \multicolumn{4}{|c|}{ LO LA HO HA } \\
\hline No. & 33 & 3 & 3 & 33 & 3 & 3 & 3 & 3 & 3 & 3 \\
\hline Low density & $+\quad+$ & & & ++ & & & & + & & \\
\hline High density & & + & + & & + & + & & & + & + \\
\hline Formic acid & + & & + & + & & + & & + & & + \\
\hline Stage of growth & $\begin{array}{l}\text { beginn } \\
\text { of flow }\end{array}$ & $\begin{array}{l}\text { hing } \\
\text { ering }\end{array}$ & & $\begin{array}{l}\text { beginni } \\
\text { of flowe }\end{array}$ & $\begin{array}{l}\text { ing } \\
\text { ering }\end{array}$ & & & ading & & \\
\hline $\mathrm{DM}, \mathrm{g} \cdot \mathrm{kg}^{-1}$ & 429 & & & 423 & & & 412 & & & \\
\hline Fertilization, $\mathrm{kg} \mathrm{N} \cdot \mathrm{ha}^{-1}$ & - & & & - & & & 70 & & & \\
\hline Low density, $\mathrm{kg} \cdot \mathrm{m}^{-3}$ & 122.5 & & & 123.1 & & & & 7.3 & & \\
\hline High density, $\mathrm{kg} \cdot \mathrm{m}^{-3}$ & 189.2 & & & 190.2 & & & & 9.7 & & \\
\hline
\end{tabular}

LO - low density, no additive; LA - low density, with FA; HO - high density, no additive; $\mathrm{HA}$ - high density, with FA

To prevent differences in dry matter content between silages, both balers were operated simultaneously. Baled silages with and without formic acid were produced alternately by each baler, by turning the additive applicator on and off. The time between bale forming and wrapping with six layers of white 30 micrometre stretch film did not exceed $60 \mathrm{~min}$. Wrapped silage bales were stored in the vertical position.

Bale density $\left(\mathrm{kg} \mathrm{DM} \cdot \mathrm{m}^{-3}\right)$ was determined based on the weight of wrapped bales, the DM content of forage and bale volume calculated as the volume of a cylinder. Forty-five days after forming the bales, samples were taken from each one with a probe $(\varnothing 20 \mathrm{~mm})$ at the diameter line and half height of the bale to a depth of $40 \mathrm{~cm}$ (Hancock and Collins, 2006). Silage samples were stored at $-25^{\circ} \mathrm{C}$. 
After defrosting, some of silage samples were dried at $40^{\circ} \mathrm{C}$ using air flow dryers (Binder FED 720, Germany), and were ground in a Retsch 200 mill (Retsch Co.) to pass through a $1.5 \mathrm{~mm}$ screen for in situ studies and through a $1 \mathrm{~mm}$ screen for chemical composition analysis.

\section{Ruminal degradation}

Effective degradation (ED) of DM and CP, and degradability parameters $(a, b, c)$ were determined by the in situ method proposed by Michalet-Doreau et al. (1987) on three non-lactating cows fitted with rumen cannulas. The animals were fed twice a day a standard maintenance diet consisting of $70 \%$ forage and $30 \%$ concentrate on a dry matter basis at maintenance level. Approximately $3 \mathrm{~g}$ of samples (ground to pass through a $1.5 \mathrm{~mm}$ screen) were placed in polyester bags $(8 \times 11 \mathrm{~cm}$ with a pore size of $42 \mu \mathrm{m}$ ) and incubated for 2, 4, 8, 16, 24 and 48 $\mathrm{h}$ (three replicates per sample and incubation time) in the rumen. After incubation, the bags were rinsed under cold tap water to remove excess ruminal contents and then were washed in an automatic washing machine (three cycles of cold water rinsing and spinning, total time $18 \mathrm{~min}$ ). The residuals in nylon bags were dried in an air-draught forced air oven at $60^{\circ} \mathrm{C}$ for $48 \mathrm{~h}$, and the residual $\mathrm{DM}$ and $\mathrm{CP}$ were used to calculate DM and CP disappearance at each incubation time. Washing losses were determined for $0 \mathrm{~h}$ incubation. The analyses were performed at the Kielanowski Institute of Animal Physiology and Nutrition, Polish Academy of Sciences in Jabłonna.

The disappearance of silage DM and CP after 45 days of fermentation was fitted to the model of Ørskov and McDonald (1979) at a ruminal outflow $(k)$ of $0.06 \mathrm{~h}^{-1}$ using non-linear regression procedures (SAS, 1995). The effective degradation of CP and degradability rate constants $(a, b, c)$ were calculated as:

$$
\mathrm{ED}=a+(b c) /(c+k p) \text { assuming } k p=0.06 \mathrm{~h}^{-1}
$$

where: $a$ - rapidly degradable fraction, $b$ - slowly degradable fraction, $c$ - rate of degradation $\left(\% \mathrm{~h}^{-1}\right)$, $k p$ - passage rate. The same model was used to calculate the effective degradation of DM.

All data were subjected to two-way ANOVA using the GLM procedure of SAS (1995). Differences between means were estimated by Duncan's multiple range test.

\section{Chemical analyses}

The content of DM and total $\mathrm{CP}$ in silages and in the residue after each hour of incubation in the rumen was estimated according to AOAC (2005). The protein nitrogen content of silages was determined as described by Licitra et al. (1996). Acid detergent fibre (ADF), neutral detergent fibre (NDF) and acid detergent lignin (ADL) were measured according to the method of Van Soest et al. (1991). Cellulose and hemicelluloses were computed as ADF minus ADL and NDF minus ADF, respectively. Insoluble nitrogen in neutral detergent (NDIN) and in acid detergent (ADIN) solutions was determined by Kjeldahl analysis of the NDF and ADF residues, respectively. All chemical analyses were performed in duplicate on each individual sample. The content of DM, structural components, total nitrogen and nitrogen fractions in silages after 45 days of fermentation are presented in Table 1. The dry matter content in silage was corrected for volatiles (Haigh, 1995) using the following equation for silage produced in bales:
DM corrected $\left(\mathrm{g} \cdot \mathrm{kg}^{-1}\right)=17.9+0.99 \mathrm{DM}\left(\mathrm{g} \cdot \mathrm{kg}^{-1}\right)$ $\left(R^{2}=0.99\right)$

Table 1. Chemical composition ( $\left.\mathrm{g} \cdot \mathrm{kg}^{-1} \mathrm{DM}\right)$ and nitrogen fractions $\left(\mathrm{g} \cdot \mathrm{kg}^{-1} \mathrm{TN}\right)$ of lucerne, red clover and red fescue silages

\begin{tabular}{|c|c|c|c|c|}
\hline \multirow{2}{*}{ Specification } & \multicolumn{2}{|l|}{ Low density } & \multicolumn{2}{|l|}{ High density } \\
\hline & no additive & FA & no additive & FA \\
\hline \multicolumn{5}{|l|}{ Lucerne } \\
\hline dry matter $\mathrm{g} \cdot \mathrm{kg}^{-1} \mathrm{FM}$ & 439 & 447 & 420 & 445 \\
\hline NDF & 487 & 466 & 511 & 520 \\
\hline ADF & 424 & 400 & 404 & 429 \\
\hline hemicellulose & 63 & 66 & 107 & 91 \\
\hline cellulose & 328 & 305 & 299 & 326 \\
\hline $\mathrm{ADL}$ & 96 & 95 & 105 & 103 \\
\hline total nitrogen & 28.1 & 27.8 & 28.0 & 28.4 \\
\hline protein nitrogen & 371 & 403 & 538 & 486 \\
\hline NDIN & 110 & 111 & 127 & 125 \\
\hline ADIN & 95.7 & 101 & 121 & 115 \\
\hline \multicolumn{5}{|l|}{ Red clover } \\
\hline dry matter $\mathrm{g} \cdot \mathrm{kg}^{-1} \mathrm{FM}$ & 438 & 421 & 447 & 440 \\
\hline NDF & 554 & 519 & 570 & 514 \\
\hline ADF & 450 & 415 & 454 & 418 \\
\hline hemicellulose & 104 & 104 & 116 & 96 \\
\hline cellulose & 360 & 326 & 341 & 330 \\
\hline $\mathrm{ADL}$ & 90 & 89 & 113 & 88 \\
\hline total nitrogen & 25.5 & 25.1 & 27.1 & 25.6 \\
\hline protein nitrogen & 625 & 561 & 624 & 581 \\
\hline NDIN & 252 & 250 & 250 & 242 \\
\hline ADIN & 186 & 205 & 136 & 160 \\
\hline \multicolumn{5}{|l|}{ Red fescue } \\
\hline dry matter $\mathrm{g} \cdot \mathrm{kg}^{-1} \mathrm{FM}$ & 485 & 433 & 437 & 453 \\
\hline NDF & 617 & 642 & 598 & 590 \\
\hline ADF & 410 & 445 & 408 & 429 \\
\hline cellulose & 345 & 383 & 346 & 367 \\
\hline hemicellulose & 207 & 197 & 190 & 161 \\
\hline$A D L$ & 65 & 62 & 62 & 62 \\
\hline total nitrogen & 16.5 & 15.9 & 17.0 & 18.4 \\
\hline protein nitrogen & 564 & 549 & 538 & 595 \\
\hline NDIN & 174 & 202 & 190 & 211 \\
\hline ADIN & 165 & 172 & 141 & 153 \\
\hline
\end{tabular}

FA - formic acid in the amount of 5 litres $\mathrm{t}^{-1}$; NDIN - insoluble nitrogen in neutral detergent; $A D I N$ - insoluble nitrogen in acid detergent 


\section{Results}

Data on the rumen degradation kinetics of DM and $\mathrm{CP}$ for lucerne, red clover and red fescue silages are presented in Table 2. The highest loss of DM and nitrogen compounds was observed throughout the incubation of lucerne silage. The effective degradation of DM and CP of lucerne silage reached significantly $(P<0.01)$ higher values, compared with red clover and red fescue silages. After 45 days of fermentation, $a$ value of lucerne silage was significantly higher, which immediately disappears from the bag. The insoluble fraction $b$ of DM and $\mathrm{CP}$ was highly degradable, as reflected by a high rate of degradation. The effective degradation of DM of red clover and red fescue silages was at a similar level (52\%-53\%), and was lower than the effective degradation of CP $(56 \%-58 \%)$. In comparison with lucerne silage, red clover and red fescue silages had a lower $(P<0.01)$ content of rumen-degradable DM. Similar, but less pronounced, differences werenoted for CP. Insoluble DM fraction $b$, potentially degradable, but at a slow rate (parameter $c$ ), dominated in red clover and red fescue silages.

\section{Degradability parameters of dry matter}

The effects of treatments on the DM and CP degradation characteristics of the examined silages are presented in Tables 3 and 4, respectively. The silages were compared with respect to the additive used and bale density (low vs high) measured as DM per $\mathrm{m}^{3}$ of the ensiled material. The experimental factors had no significant effect on the effective degradation of DM of wilted lucerne silage, while DM degradation characteristics were significantly affected by the treatments. The washing loss of DM was higher $(P<0.05)$ in FA-treated lucerne silage, due to an increase in the concentrations of rapidly degradable nitrogen fraction $a$ (Table 4). Higher bale density reduced $(P<0.05)$ the rate of DM degradation $\left(0.074 \mathrm{~h}^{-1} \mathrm{vs} 0.089 \mathrm{~h}^{-1}\right)$, which could have resulted from an increase in the concentrations of NDF, ADIN and NDIN (Table 1).

Higher bale density of red clover silage and the addition of FA decreased $(P<0.05)$ the effective degradation of DM, mostly due to a lower fraction $a$ content, particularly in the HA treatment. An influence of bale density of red clover silage on DM degradability was observed at the beginning of sample digestion in the rumen (after 2, 4 and $8 \mathrm{~h}$ of incubation). In the $8^{\text {th }} \mathrm{h}$ of sample incubation, an interaction $(P<0.01)$ was noted between the experimental factors affecting the fermentation process. The experimental treatments had no effect on the effective degradation of DM of red fescue silage. The noted values were lowest and similar (52\%-54\%).

The content of rapidly degradable fraction $a$ was low and also remained at a similar level. No-additive silages and FA-treated ensiled grasses differed significantly with regard to the values of modelling parameters $b$ and $c$. Degradation rate $c$ of fraction $b$ was approximately 1.6 -fold lower in additive-treated red fescue.

\section{Degradability parameters of crude protein}

The effective degradation of $\mathrm{CP}$ of lucerne silage and modelling parameters $a, b, c$ were affected by bale density and the addition of FA, and the interaction $(P<0.05)$ between the experimental

Table 2. The effect of ensiled plant species on the effective rumen degradation of DM and CP and degradability parameters $a, b, c$

\begin{tabular}{|c|c|c|c|c|c|c|c|c|}
\hline \multirow{2}{*}{ Indices } & \multicolumn{3}{|c|}{ Dry matter } & \multirow{2}{*}{ SEM } & \multicolumn{3}{|c|}{ Crude protein } & \multirow{2}{*}{ SEM } \\
\hline & lucene & red clover & red fescue & & lucene & red clover & red fescue & \\
\hline \multicolumn{9}{|l|}{ h } \\
\hline 2 & $37.7^{\mathrm{A}}$ & $29.9^{\mathrm{Ba}}$ & $27.7^{\mathrm{Bb}}$ & 0.88 & $43.2^{\mathrm{A}}$ & $29.5^{\mathrm{B}}$ & $29.2^{\mathrm{B}}$ & 1.26 \\
\hline 4 & $38.3^{A}$ & $32.5^{\mathrm{B}}$ & $32.4^{\mathrm{B}}$ & 0.62 & $38.7^{\mathrm{A}}$ & $30.8^{\mathrm{B}}$ & $30.2^{\mathrm{B}}$ & 0.88 \\
\hline 8 & $49.0^{A}$ & $39.9^{\mathrm{B}}$ & $38.3^{\mathrm{B}}$ & 0.97 & $52.1^{\mathrm{A}}$ & $36.7^{\mathrm{B}}$ & $36.2^{\mathrm{B}}$ & 1.41 \\
\hline 16 & $55.8^{\mathrm{A}}$ & $52.4^{\mathrm{B}}$ & $46.4^{\mathrm{C}}$ & 0.81 & $59.2^{\mathrm{A}}$ & $54.7^{\mathrm{B}}$ & $44.1^{\mathrm{AB}}$ & 1.26 \\
\hline 24 & $62.7^{\mathrm{A}}$ & $58.2^{\mathrm{B}}$ & $57.5^{\mathrm{B}}$ & 0.57 & $68.0^{\mathrm{A}}$ & $64.4^{\mathrm{A}}$ & $50.7^{\mathrm{B}}$ & 1.48 \\
\hline 48 & $65.6^{\mathrm{a}}$ & $65.4^{\mathrm{a}}$ & $63.4^{b}$ & 0.49 & $71.5^{A}$ & $73.2^{\mathrm{B}}$ & $55.2^{\mathrm{B}}$ & 1.67 \\
\hline ED & $59.8^{A}$ & $52.8^{B}$ & $51.9^{\mathrm{B}}$ & 0.80 & $69.5^{\mathrm{A}}$ & $55.8^{B}$ & $58.4^{\mathrm{B}}$ & 1.30 \\
\hline \multicolumn{9}{|l|}{ Fraction } \\
\hline$a$ & $30.7^{\mathrm{A}}$ & $23.2^{\mathrm{B}}$ & $22.9^{\mathrm{B}}$ & 0.58 & $34.3^{\mathrm{A}}$ & $20.4^{\mathrm{Bb}}$ & $23.9^{\mathrm{Aa}}$ & 0.99 \\
\hline$b$ & $36.0^{\mathrm{A}}$ & $46.1^{\mathrm{B}}$ & $45.7^{\mathrm{B}}$ & 0.82 & $40.5^{\mathrm{B}}$ & $59.5^{\mathrm{A}}$ & $37.7^{\mathrm{B}}$ & 1.74 \\
\hline$c$ & $0.081^{\mathrm{A}}$ & 0.062 & $0.056^{\mathrm{B}}$ & 0.003 & 0.068 & 0.057 & 0.065 & 0.003 \\
\hline
\end{tabular}

$a$ - rapidly degradable fraction, $b$ - slowly degradable fraction, $c$ - rate of degradation $\left(\% \cdot h^{-1}\right)$; ED - effective degradation; SEM - standard error of the mean; ${ }^{\mathrm{AB}, \text { ab }}$ means with different superscipts within a row are significantly different at $P \leq 0.01$ or $P \leq 0.05$, respectively 
Table 3. Treatment effects on the effective rumen degradation of dry matter $(\%)$ and degradability parameters $(a, b, c)$

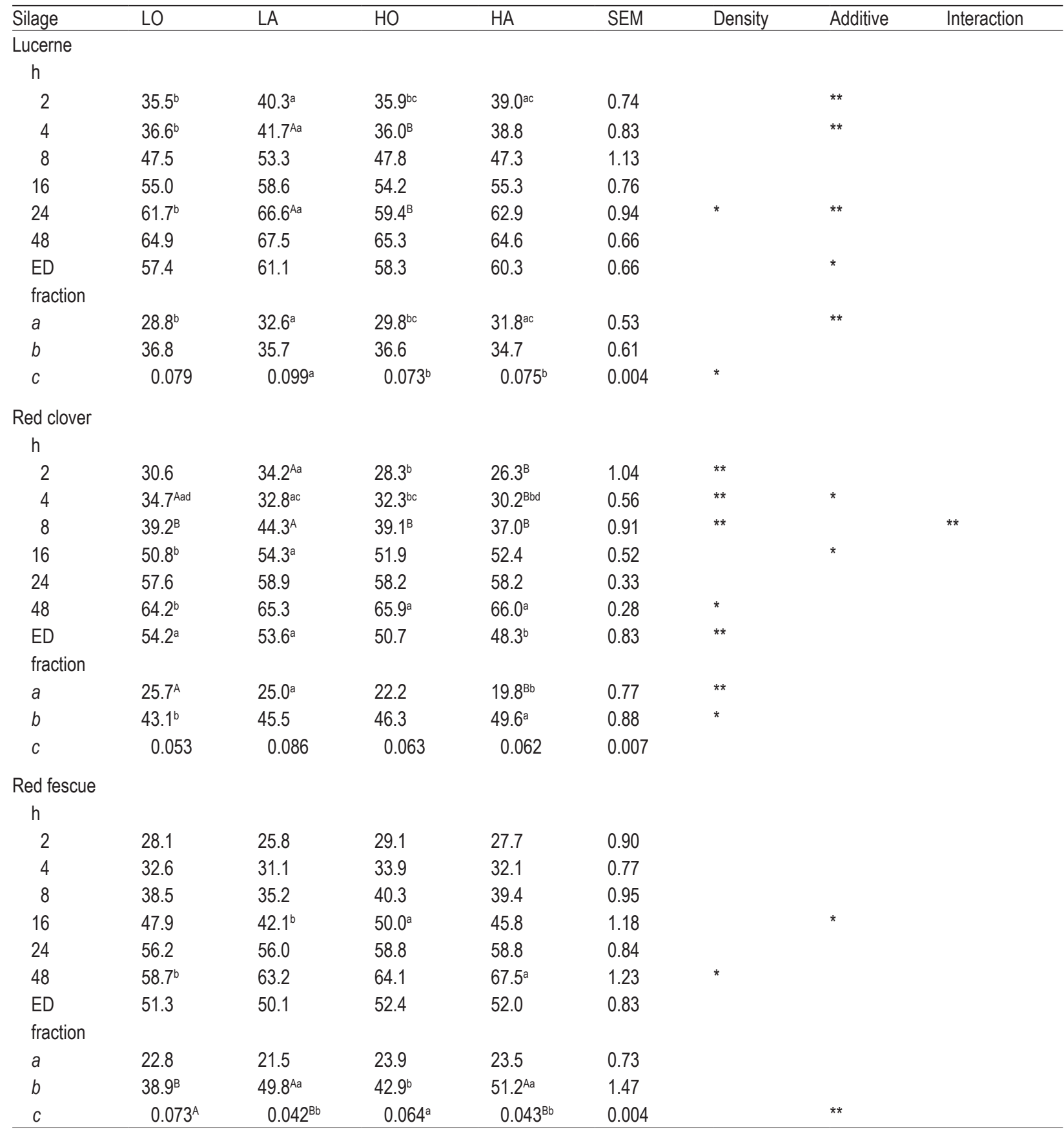

FA - formic acid; ED - effective degradation; LO - low density, no additive; LA - low density, with FA; HO - high density, no additive; HA - high density, with FA; $a$ - soluble fraction; $b$ - insoluble but degradable fraction; ${ }^{c}$ - degradation rate; SEM - standard error of the mean; means followed by different letters in the same row are significantly different: $A B$, abcd means with different superscipts within a row are significantly different at $P \leq 0.01$ or $P \leq 0.05$, respectively

factors. Both the compression level of wilted lucerne silage and FA treatment had an effect $(P<0.01)$ on the effective degradation of $\mathrm{CP}$ and the content of rapidly degradable fraction $a$. The effective degradation of CP of lucerne silage was significantly higher in FA-treated silage compared with untreated silage. Acidification of wilted forage and high bale density (treatment HA) enhanced $(P<0.01)$ the susceptibility of $\mathrm{N}$-constituents to ruminal degradation. The experimental factors also contributed to an increase in the content of rapidly degradable fraction $a$. Data regarding fraction $b$ of $\mathrm{CP}$ showed the lowest extent of rumen degradation of silage with the lowest degradation rate $c$ of fraction $b$. High bale density of lucerne silage (treatment $\mathrm{HO}$ ) had no efect on the effective degradation of $\mathrm{CP}$ and modelling parameters $(a, b, c)$ in comparison with low bale density. It should be noted that there was a significant $(P<0.05)$ interaction between the experimental factors (bale density and addition of FA) with respect 
Table 4. Treatment effects on the effective rumen degradation of crude protein (\%) and degradability parameters $(a, b, c)$

\begin{tabular}{|c|c|c|c|c|c|c|c|c|}
\hline Silage & LO & LA & $\mathrm{HO}$ & $\mathrm{HA}$ & SEM & Density & Additive & Interaction \\
\hline \multicolumn{9}{|l|}{$\begin{array}{l}\text { Lucerne } \\
\mathrm{h}\end{array}$} \\
\hline 2 & $39.3^{c}$ & $44.5^{\mathrm{B}}$ & $41.1^{\mathrm{C}}$ & $48.1^{\mathrm{A}}$ & 1.04 & ** & & \\
\hline 4 & $36.5^{b}$ & 39.5 & 37.2 & $41.5^{\mathrm{a}}$ & 0.82 & & * & \\
\hline 8 & 49.6 & 54.2 & 52.9 & 51.6 & 1.03 & & & \\
\hline 16 & 58.7 & 59.6 & 62.7 & 55.9 & 1.17 & & & \\
\hline 24 & $65.0^{\mathrm{b}}$ & $74.2^{\mathrm{a}}$ & 68.8 & $63.9^{b}$ & 1.59 & & & * \\
\hline 48 & 69.2 & 71.6 & 78.2 & 66.8 & 2.00 & & & \\
\hline $\begin{array}{l}\text { ED } \\
\text { fraction }\end{array}$ & $65.2^{\mathrm{Bb}}$ & $68.9^{\mathrm{Ba}}$ & $66.9^{\mathrm{B}}$ & $76.1^{\mathrm{A}}$ & 1.02 & ** & $* *$ & * \\
\hline a & $30.3^{\mathrm{Bb}}$ & $33.9^{\mathrm{Ba}}$ & $31.9^{\mathrm{B}}$ & $41.2^{\mathrm{A}}$ & 1.01 & ** & ** & * \\
\hline$b$ & $41.3^{\mathrm{a}}$ & 40.1 & $49.9^{A}$ & $30.6^{\mathrm{Bb}}$ & 2.13 & & ** & * \\
\hline$c$ & 0.076 & $0.083^{a}$ & 0.060 & $0.052^{b}$ & 0.005 & * & & \\
\hline \multicolumn{9}{|l|}{$\begin{array}{l}\text { Red clover } \\
\mathrm{h}\end{array}$} \\
\hline 2 & 30.0 & 26.4 & 28.0 & 33.4 & 1.41 & & & \\
\hline 4 & $34.4^{\mathrm{A}}$ & $24.0^{\mathrm{Bb}}$ & $31.4^{a}$ & $33.4^{\mathrm{A}}$ & 1.46 & & & * \\
\hline 8 & 37.9 & 34.7 & 32.6 & 41.8 & 1.58 & & & \\
\hline 16 & 53.7 & $50.7^{b}$ & 55.2 & $59.3^{a}$ & 1.37 & & & \\
\hline 24 & 65.0 & 61.1 & 63.1 & 68.5 & 1.28 & & & \\
\hline 48 & $72.2^{b}$ & $71.7^{b}$ & $70.6^{b}$ & $78.1^{\mathrm{a}}$ & 1.11 & & & * \\
\hline $\begin{array}{l}\text { ED } \\
\text { fraction }\end{array}$ & $59.9^{a}$ & $48.9^{b}$ & 54.0 & $59.0^{\mathrm{a}}$ & 1.59 & & & ** \\
\hline a & $24.9^{a}$ & $13.9^{b}$ & 19.0 & $24.0^{a}$ & 1.57 & & & ** \\
\hline$b$ & $52.5^{\mathrm{b}}$ & $64.8^{\mathrm{a}}$ & 59.9 & 61.0 & 1.86 & & & \\
\hline$c$ & 0.050 & 0.066 & 0.056 & 0.054 & 0.004 & & & \\
\hline \multicolumn{9}{|l|}{ Red fescue } \\
\hline 2 & 28.6 & 27.8 & 30.5 & 30.0 & 0.65 & & & \\
\hline 4 & 31.3 & 29.3 & 29.4 & 30.9 & 0.76 & & & \\
\hline 8 & $36.0^{\mathrm{a}}$ & $32.4^{\mathrm{Bb}}$ & $37.7^{A}$ & $38.6^{\mathrm{A}}$ & 0.81 & $* *$ & & * \\
\hline 16 & $45.7^{a}$ & $40.3^{b}$ & 45.2 & 45.0 & 0.92 & & & \\
\hline 24 & $48.7^{b}$ & $48.1^{b}$ & 50.1 & $56.0^{a}$ & 1.25 & * & & \\
\hline 48 & $50.5^{b}$ & $53.9^{b}$ & $52.9^{b}$ & $63.4^{\mathrm{a}}$ & 1.88 & & * & \\
\hline $\begin{array}{l}\text { ED } \\
\text { fraction }\end{array}$ & 58.0 & 58.3 & 59.4 & 59.7 & 1.03 & & & \\
\hline a & 23.0 & 23.3 & 24.4 & 24.7 & 0.99 & & & \\
\hline$b$ & 30.8 & 44.0 & 32.6 & 43.5 & 2.81 & & & \\
\hline$c$ & 0.092 & 0.052 & 0.070 & 0.048 & 0.008 & & & \\
\hline
\end{tabular}

FA - formic acid; ED - effective degradation; LO - low density, no additive; LA - low density, with FA; HO - high density, no additive; HA high density, with FA; $a$ - soluble fraction; $b$ - insoluble but degradable fraction; $c$ - degradation rate; SEM - standard error of the mean. ${ }_{A B}, a b$ means with different superscipts within a row are significantly different at $P \leq 0.01$ or $P \leq 0.05$, respectively

to the effective degradation of $\mathrm{CP}$ and both fractions ( $a$ and $b$ ).

FA treatment $(\mathrm{LA})$ decreased $(P<0.05)$ the effective degradation of $\mathrm{CP}$ of red clover silage $(48.9 \%$ vs $59.9 \%)$ and reduced $(P<0.05)$ the content of rapidly degradable fraction $a$. At the same time, the slowly degradable fraction $b$ enhanced $c(P<0.05)$, and the rate of degradation tended to be faster. It should be stressed that there was an interaction $(P<0.01)$ between the experimental factors with respect to the effective degradation of $\mathrm{CP}$ and the content of rapidly degradable fraction $a$. In contrast to legume silages, the $\mathrm{CP}$ degradation kinetics of red fescue silage during the first four hours of fermentation in the rumen did not differ between treatments. Significant differences in CP degradation were noted starting from the $8^{\text {th }} \mathrm{h}$ of sample incubation. A more rapid degradation rate of $\mathrm{N}$-constituents was observed in the $8^{\text {th }} \mathrm{h}$ of incubation in treatments HO and HA. There were no significant differences between treatments in the effective degradation of $\mathrm{CP}$ and modelling parameters $(a$, $b, c)$. Nonetheless, FA-treated red fescue silage tended to have a higher content of fraction $b$ (43.8\% vs $31.7 \%$ on average) and a slower rate of degradation of fraction $b$. Similar relationships were noted in the DM degradability of red fescue silage (Table 3). 


\section{Discussion}

The conditions of bacterial activity and growth vary depending on the species of ensiled crops and the additives used during ensilage. Forage legumes differ considerably with respect to their susceptibility to proteolytic attack by rumen microorganisms. Protein in red clover has been found to be degraded less extensively in the rumen than the protein in other non-tannin legumes (Broderick and Albrecht, 1997; Cassida et al., 2000; Broderick et al., 2004). Our results confirmed the higher susceptibility of DM and CP of lucerne silage (cv. Alba) to ruminal degradation in comparison with red clover (cv. Godolin) silage. Significantly $(P<0.01)$ reduced susceptibility of red clover DM to ruminal degradation, as compared with lucerne DM, could result from higher concentrations of slowly degradable fractions and higher levels of NDIN and ADIN in red clover. Lucerne silage has a higher content of $\mathrm{DM}$ and $\mathrm{CP}$ soluble fractions than red clover silage. The protein degradation rate of fraction $b$ was also higher in lucerne silage. Similar relationships were reported by Broderick et al. (2004) who compared the parameters of protein degradability in lucerne silage and silages made from genetically different red clover varieties. According to the information quoted by the above authors, polyphenol oxidase (PPO) - an enzyme naturally present in red clover may have generated $o$-quinones that react with fraction $a$ and other proteins that supply $\mathrm{N}$ for microbial synthesis of protein. This reduces the breakdown of protein in the rumen. A similar situation can be observed in a silo where $o$-quinones generated by PPO action may exert an inhibitory effect on red clover proteases, thus reducing rumen protein degradability. In the present study, DM degradability of red clover silage was lower $(P<0.01)$ compared with lucerne silage, which could be related to higher concentrations of slowly degradable fractions and higher levels of NDIN and ADIN.

In the ensiling process, chemical additives are used to inhibit enzyme activity in the ensiled crop, thus reducing proteolysis and accumulation of NPN that consists principally of free amino acid-N $\left(\right.$ FAA-N), peptide- $\mathrm{N}$ and ammonia- $\mathrm{N}\left(\mathrm{NH}_{3}-\mathrm{N}\right)$. Most published research findings show that the content of NPN, $\mathrm{NH}_{3}-\mathrm{N}$ and FAA-N is significantly lower in chemically-treated silages. Since FA effectively reduces plant enzymatic activity, the amount of protein that had not been hydrolysed during fermentation is expected to be higher in early stages of the ensiling process. Guo et al. (2007) demonstrated that the reduction of proteolysis by FA is probably due to acidifying the forage below the $\mathrm{pH}$ optima of plant protease. In the cited study, FA and formaldehyde effectively inhibited proteolysis after half a day of ensiling, and tannic acid, after one day. The inhibition of proteolysis may be reflected in reduced rumen protein degradability in acidified legume or grass silages. Pursiainen and Tuori (2008) and Lorenz et al. (2010) demonstrated decreased protein degradation in preserved silages. In contrast, Siddons et al. (1982) showed no effect or only slightly reduced degradability of protein in FA-treated ryegrass or red clover silages; more effective than FA alone was a mixture of FA and formaldehyde.

The current results show that FA exerted a significant effect only in red clover ensiled at a low degree of compression. The decrease $(P<0.05)$ in CP degradability and lower $(P<0.05)$ solubility resulting from the $a$ value observed in our study are consistent with the findings of other authors. The parameters of rumen protein degradability in the above treatment were correlated with the concentrations of protein-N and ADIN. In the present experiment, the highest amount of ADIN in total $\mathrm{N}$ affected $(P<0.05)$ degradability parameters $a$ and $b$, leading to a significant decrease in the effective degradation of CP. The loss of readily fermentable substances and the possible Maillard reaction between fibre and proteins in the treated silage of red clover probably reduced CP degradability. It seems interesting that the effective degradation of DM was reduced in treatment HA (Table 3 ). When red clover was ensiled with FA at higher bale density, the effective degradation of DM was lower $(P<0.05)$ due to lower protein solubility ( $a$ value). The changes in the effective degradation of $\mathrm{CP}$ of lucerne ensiled with FA at different compression levels are difficult to explain, however. A significant interaction $(P<0.05)$ was observed between the experimental factors. High bale density combined with FA addition increased $(P<0.01)$ modelling degradability parameter $a$, and enhanced the effective degradation of CP. Similar, but less pronounced $(P<0.05)$, trends were observed in treatment LA. It should be noted that the rate of CP and (in particular) DM degradation was more rapid during the first few hours of ruminal incubation of legume silages. Lättemäe et al. (1996) also found the largest differences during the first $12 \mathrm{~h}$ of ruminal incubation in the degradability characteristics in red clover silages submitted to treatment with FA and molasses. Some research (Rodrigues et al., 2002; Hetta et al., 2003) has shown that the degradation kinetics during the first $12 \mathrm{~h}$ of fermentation in the rumen can be important in predicting forage intake. Unlike legume silages, red fescue 
silage was more intensely degraded in the rumen only after 8 or $16 \mathrm{~h}$ of incubation, which could be due to a lower content of rapidly degradable fraction $a$ of $\mathrm{CP}$ and DM. In comparison with legume silages, DM of red fescue silage has low concentrations of ADL and high levels of hemicellulose and cellulose. As a result, rumen DM degradability of red fescue silage is comparable with that of red clover silage.

To our best knowledge, the degradability characteristics of red fescue silage have not been previously described. Only Bruinenberg et al. (2002) reported in a review article that in vitro organic matter digestibility (OMD) of red fescue green forage in the first and second year of growth was 0.72 , and in the fourth year, 0.62 ; the respective values for ryegrass (Lolium perenne), which is used as a reference standard, were 0.80 and 0.73 . Our findings also indicate that red fescue and red clover silages were characterized by a similar degree of microbial degradation of DM and nitrogen compounds in the rumen and similar degradability parameters. The addition of FA and bale density had no significant effect on the effective degradation of $\mathrm{DM}$ and $\mathrm{CP}$.

\section{Conclusions}

Bale density and the addition of formic acid may affect the effective degradability of crude protein in lucerne silages while these factors do not affect the effective degradability of dry matter and crude protein in red fescue ensiled in round bales.

\section{Acknowledgements}

Supported by the State Committee for Scientific Research, Grant No. N N311 234238.

\section{References}

AOAC, 2005. Association of Official Analytical Chemists, Official Methods of Analysis. $18^{\text {th }}$ Edition. Arlington, VA

Broderick G.A., Albrecht K.A., 1997. Ruminal in vitro degradation of protein in tannin-free and tannin-containing forage legume species. Crop Sci. 37, 1884-1891

Broderick G.A., Albrecht K.A., Owens V.N., Smith R.R., 2004. Genetic variation in red clover for rumen protein degradability. Anim. Feed Sci. Tech. 113, 157-167

Bruinenberg M.H., Valk H., Korevaar H., Struik P.C., 2002. Factors affecting digestibility of temperate forages from seminatural grasslands: a review. Grass Forage Sci. 57, 292-301

Cassida K.A., Griffin T.S., Rodriguez J., Patching S.C., Hesterman O.B., Rust S.R., 2000. Protein degradability and forage quality in maturing alfalfa, red clover, and birdsfoot trefoil. Crop Sci. 40, 209-215
Guo X., Zhou H., Yu Z., Zhang Y., 2007. Changes in the distribution of nitrogen and plant enzymatic activity during ensilage of lucerne treated with different additives. Grass Forage Sci. 62, 35-43

Haigh P.M., 1995. A note of relationship between oven and toluene determined dry matter concentrations in big-bale grass silages. Irish J. Agr. Food Res. 63, 189-191

Han K.J., Collins M., Vanzant E.S., Dougherty C.T., 2006. Characteristics of baled silage made from first and second harvests of wilted and severely wilted forages. Grass Forage Sci. 61, 22-31

Hancock D.W., Collins M., 2006. Forage preservation method influences alfalfa nutritive value and feeding characteristics. Crop Sci. 46, 688-694

Hetta M., Cone J.W., Gustavsson A.M., Martinnson K., 2003. The effect of additive in silages of pure timothy and timothy mixed with red clover on chemical composition and in vitro rumen fermentation characteristics. Grass Forage Sci. 58, 249-257

Jones R., 2000. Understanding the processes of protein degradation in forage crops provide opportunities for improved silage quality and enhanced animal production. In: T.P. Lyons, K.A. Jacques (Editors). Proceedings of Alltech's $16^{\text {th }}$ Annual Symposium on Nutritional Biotechnology in the Feed and Food Industries. Nottingham University Press, pp. 423-437

Lättemäe P., Ohlsson C., Lingvall P., 1996. The combined effect of molasses and formic-acid on quality of red clover silage. Swed. J. Agr. Res. 26, 31-41

Licitra G., Hernandez T.M., Van Soest P.J., 1996. Standardization of procedures for nitrogen fraction of ruminant feeds. Anim. Feed Sci. Tech. 57, 347-358

Lorenz M.M., Eriksson T., Uden P., 2010. Effects of wilting, silage additive, PEG treatment and tannin content on the distribution of $\mathrm{N}$ between different fractions after ensiling of three different sainfoin (Onobrychis viciifolia) varieties. Grass Forage Sci. $65,175-184$

Michalet-Doreau B., Verité R., Chapoutot P., 1987. Methodologie de la degradabilité in sacco de l'azote des aliments dans le rumen. Bull. Tech. C.R.Z.V. Theix, INRA 69, 5-7

Pursiainen P., Tuori M., 2008. Effect of ensiling field bean, field pea and common vetch in different proportion with whole-crop wheat using formic acid or an inoculant on fermentation characteristics. Grass Forage Sci. 63, 60-78

Purwin C., 2007. Quality of the grass and grass-legume silage made by baler technology (in Polish). Dissertations and Monographs. Univeristy of Warmia and Mazury in Olsztyn (Poland)

Ørskov E.R., McDonald I., 1979. The estimation of protein degradability in the rumen from incubation measurements weighed according to rate of passage. J. Agr. Sci. 92, 499-503

Rodrigues M.A.M., Fonseca A.J.M., Sequeira C.A., Dias Da Silva A.A., 2002. Digestion kinetic parameters from an in vitro gas production method as predictors of voluntary intake of forage by mature ewes. Anim. Feed Sci. Tech. 95, 133-142

SAS, 1995. Release 6.11. SAS Institute INC. Cary, NC

Siddons R.C., Beever D.E., Kaiser A.L., 1982. Evaluation of the effect of formic acid and level of formaldehyde application before ensiling on silage protein degradability. J. Sci. Food Agr. 33, 609-613

Slottner D., Bertilsson J., 2006. Effect of ensiling technology on protein degradation during ensilage. Anim. Feed Sci. Tech. 127, 101-111

Van Soest P.J., Robertson J.B., Lewis B.A., 1991. Carbohydrate methodology, metabolism and nutritional implications in dairy cattle: Methods for dietary fiber, neutral detergent fiber and nonstarch polysaccharides in relation to animal nutrition. J. Dairy Sci. 74, 3583-3597 